\title{
Epidemiology and dynamics of shell disease in the edible crab Cancer pagurus: a preliminary study of Langland Bay, Swansea, UK
}

\author{
Claire L. Vogan, Paul J. Llewellyn, Andrew F. Rowley* \\ School of Biological Sciences, University of Wales Swansea, Singleton Park, Swansea, SA2 8PP, United Kingdom
}

\begin{abstract}
The prevalence and severity of shell disease in the edible crab Cancer pagurus (L.) was investigated in animals collected from Langland Bay, Gower, South Wales, UK, at monthly intervals from 1997 to 1998. Shell disease is the progressive degradation of exoskeletal chitin accompanied by melanisation of the affected region. Over $50 \%$ of the crabs sampled had 1 or more black-spot lesions. The proportion of exoskeleton affected increased with the size of the crab. Male crabs showed significantly higher levels of the disease than females, a higher prevalence of black-spot lesions $163 \%$ in males, $40 \%$ in females) and a higher mean percentage of body covered by lesions (1\% in males, $0.2 \%$ in females). This difference between the sexes corresponded to an increase in ventral surface and chela infection in males. For both sexes, the dorsal carapace was the area most affected by the disease. Dorsal carapace regional breakdown revealed the areas most commonly affected were located to the posterior of the crab. Lesion location patterns suggested that sand abrasion injuries during back-burrowing behaviour of $C$. pagurus lead to the formation of shell disease lesions. Seasonal trends in shell disease were seen to be dependent on the onshore migration patterns of the different size classes and sexes over the sampling period.
\end{abstract}

KEY WORDS: Shell disease - Chitin degradation - Cancer pagurus · Crustacea

\section{INTRODUCTION}

Shell disease is the progressive degradation of exoskeletal chitin accompanied by melanisation of the affected region. Otherwise known as black spot, rust spot or burned spot, the disease affects numerous crustacean species worldwide (for review see Getchell 1989). Both bacteria and fungi have been implicated as shell disease pathogens, with the ability to produce chitindigesting enzymes a vital requirement (Rosen 1970). Cipriani et al. (1980) suggested that the lesions act as micro-niches, nutturing several taxonomic groups that produce a suite of extracellular enzymes which collectively lead to the progression of the disease. Although the disease manifests as a single syndrome, lesion synecology is likely to vary considerably through time and according to the geographic location of the host.

\footnotetext{
- Addressee for correspondence.

E-mail: a.f.rowley@swansea.ac.uk
}

Epicuticular penetration is required before the chitinous endocuticle is exposed for microbial colonisation and degradation. This may occur by mechanical abrasion (Sindermann \& Rosenfield 1967, Cook \& Loften 1973), wounding (Abbott 1977, Nottage 1982, Dyrynda 1998), chemical attack (Doughtie \& Rao 1981, Weinstein et al. 1992) or microbial attack (Baross et al. 1978, Cipriani et al. 1980, Smolowitz et al. 1992). The disease seems particularly prevalent in areas of degraded habitat. High levels of infection have been found in crustaceans from the heavily polluted waters of the New York Bight, USA (Gopalan \& Young 1975, Young \& Pearce 1975), as well as in the elevated population densities of aquaculture systems (Fisher et al. 1978, Sindermann 1984).

Crustaceans can rid themselves of superficial infections of shell disease by moulting (Smolowitz et al. 1992). Mortality can occur when the disease penetrates the exoskeleton either by secondary invasion of the haemolymph by pathogenic bacteria (Baross et al. 1978) or by 
adhesion between the old and new shells at the lesion site, leading to incomplete withdrawal during ecdysis (Fisher et al. 1978, Smolowitz et al. 1992). Impairment of functions such as feeding and locomotion, or increased vulnerability to irreparable damage in cannibalistic attacks (Dyrynda 1998) can result from the brittle exoskeletal lesion material and may eventually lead to the death of the animal.

For commercial fisheries the black, blotchy appearance of diseased crabs reduces their market value and acceptability. Pearson (1908) was the first to describe shell disease in the European edible crab Cancer pagurus. Between 1969 and 1980 catch-rejection for C. pagurus as a result of sheil disease was estimated at $<1 \%$ in Norfolk and Yorkshire (UK), $2 \%$ in Dorset (UK) and 5 to $7 \%$ in Ireland (Ayres \& Edwards 1982). Comely \& Ansell (1989) found high prevalences (88\%) of black-spot lesions in C. pagurus from the west coast of Scotland. However, this report was based on a small sample (57 individuals). Prior to their study, the prevalence of shell disease in natural populations rarely exceeded 10\% (Baross et al. 1978).

Therefore, the aim of this study was to investigate the natural occurrence of shell disease in the Cancer pagurus population of Langland Bay, Swansea, South Wales, based on a sample size of 500 crabs. The prevalence and severity of the disease was assessed according to the size and sex of individuals. The most commonly infected exoskeletal areas were established and lesion location patterns explained according to the behaviour of $C$. pagurus. This work forms part of a long-term study of shell disease fluctuations in response to changes in pollution control measures in the Swansea area.

\section{METHODS}

Field survey. A monthly shore survey for Cancer pagurus was conducted around Langland Bay on the Gower Peninsula of South Wales, UK (Fig. 1). The peninsula juts into the waters of the Bristol Channel and the tides of this region have the largest diurnal range $(13 \mathrm{~m})$ found in Britain. Sampling occurred on spring tides that measured less than $1.5 \mathrm{~m}$ above chart datum, along the rocky shores above the low tide mark where crabs shelter in holes to moult and mate. The sample area varied on each sampling occasion, being defined by the height of the tide, both in terms of vertical range and accessibility of the east-west extremi- ties. All crabs collected were sexed, their carapace width measured (to the nearest $\mathrm{mm}$ ) and limb loss noted. The size and position of lesions on the external surface of each crab were recorded onto a standard $C$. pagurus outline (adapted from Warner 1977) from which an estimate of the percentage of the exoskeleton covered by lesions could be calculated. The dorsal carapace was sub-divided into 28 regions of equal area, thus enabling the precise location of dorsal carapace lesions to be mapped. Ecdysed crabs of moult stages A and B (according to Drach 1939) were not included in this study, as they showed no melanin expression at these stages of their moult cycle (Anderson \& Conroy 1968, Chan et al. 1988).

Statistical analyses. Prevalences of disease and limb loss data were analysed using contingency tables combined with the Fisher's exact test or chi-square test. All other data are shown as mean values \pm SE and analysed using an appropriate parametric test (Student's $t$-test where only 2 sample groups existed, ANOVA for multiple group comparison followed by Tukey's post-test to distinguish where any significant differences lay). When data resisted transformation to normality, the equivalent non-parametric test (MannWhitney $U$-test) was applied.

\section{RESULTS}

\section{General observations}

Cancer pagurus was predominantly found in sandy holes and crevices amongst the intertidally exposed 
rock of the sample area. Intermoult males were frequently observed in attendance to premoult and postmoult females (Edwards 1979). On no occasion, however, was mating between a newly ecdysed female and hard-shelled male witnessed. Unaccompanied crabs were usually found partially buried in the sediment towards the back of the hole. Banking of the sediment at the entrance to the hole was often an indication of its occupation.

At all times of the year there were more male crabs onshore than females (Fig. 2). The relative proportion of females generally increased between April and September. Although the mean size of males (105 \pm $1.3 \mathrm{~mm} ; \mathrm{n}=333)$ and females (104 $\pm 1.7 \mathrm{~mm} ; \mathrm{n}=167)$ was not significantly different, the range of size classes throughout the year was greater in males. The 2 largest female size classes were only present onshore between May and October. In contrast, the equivalent male classes made up a larger proportion of the crabs and persisted onshore for a longer period (April to January).

\section{Prevalence and severity of shell disease}

Crabs from Langland Bay showed a $55.4 \%$ yearly average prevalence of shell disease (i.e. individuals displaying 1 or more exoskeletal black-spot lesions). Prevalence ranged from a minimum of $41.2 \%$ in May and January to a maximum of $87.5 \%$ in December
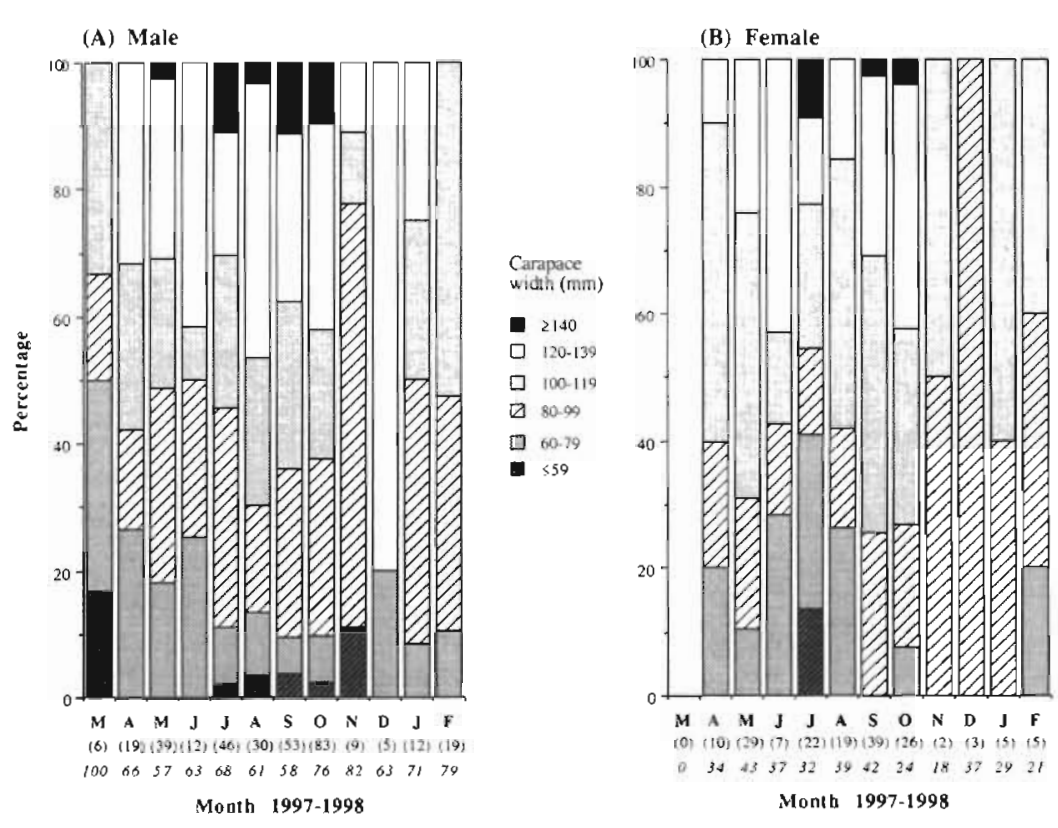

Fig. 2. Cancer pagurus. Size distributions of male (A) and female (B) crabs observed onshore at the sample sites between March (1997) and February (1998). Numbers in parentheses: sample sizes. Numbers in italics: percentage of male or female crabs from total sampled each month

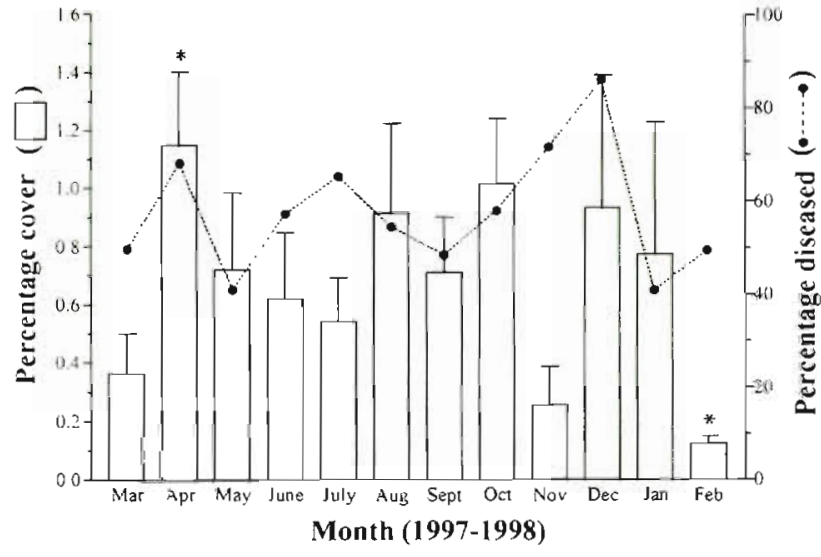

Fig. 3. Cancer pagurus. Seasonal variations in shell disease showing the percentage of diseased crabs in the monthly shore surveys and the mean percentage $(+\mathrm{SE})$ of exoskeletal surface covered by lesions amongst diseased individuals. - Significant differences in severity between months identified by ANOVA followed by Tukey's multiple comparisons $(\mathrm{p}<0.05)$

(Fig. 3) but showed no clearly defined seasonal trends (chi-square, $p=0.054$ ). Amongst the diseased individuals, significant differences in severity existed between April 1997 and February 1998.

Shell disease was more common as the carapace width (CW) of the crabs increased (chi-square, $p<0.0001$ ) (Fig. 4A). Within the largest size class, which represents the legal-sized crabs ( $\geq 140 \mathrm{~mm} \mathrm{CW}$ ), $88 \%$ of individuals showed signs of the disease. The proportion of exoskeleton covered with lesions also increased with the size of the crab (Fig. 4B). The highest severity of the disease occurred within the 120 to $139 \mathrm{~mm}$ size class $(1.9 \pm 0.2$ percent of body covered by lesions; $n=100$ ).

Important differences in the occurrence of the disease existed between the sexes. Of all males sampled, $63.1 \%$ had 1 or more lesions on their exoskeleton, compared to $40.1 \%$ in females (Fisher's exact, $\mathrm{p}<0.0001$ ). Significant differences also were found in the severity of the disease between infected males $(1.0 \pm 0.1$ percent of exoskeleton covered by lesions; $\mathrm{n}=$ $210)$ and females $(0.2 \pm 0.3$ percent of exoskeleton covered by lesions; $n=67$ ) (Mann-Whitney, $p<0.0001$ ). For both sexes, the most commonly affected body part was the dorsal carapace (Fig. 5). In females, the infection was frequently restricted to the dorsal carapace $(52.2 \%$ of all females col- 

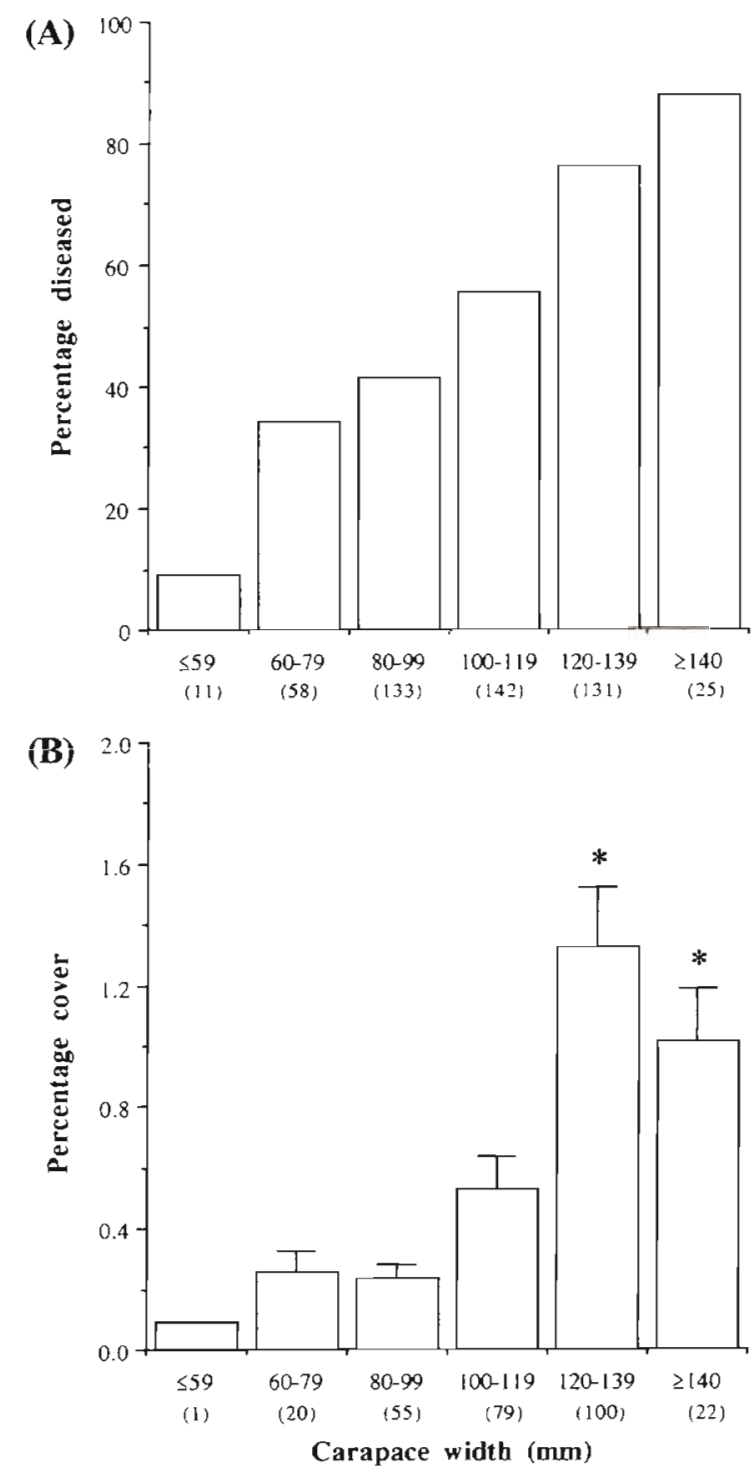

Fig. 4. Cancer pagurus. Effect of host size on shell disease. (A) Prevalence of lesion occurrence within each size class. (B) Mean percentage (+SE) of exoskeletal surface covered by lesions amongst diseased individuals from each size class. - Significantly different (ANOVA followed by Tukey's multiple comparisons, $p<0.05$ ) to size classes 100 to $119 \mathrm{~mm}$ and below ( $\leq 59 \mathrm{~mm}$ size class omitted due to a sample size of 1 ). Numbers in parentheses: sample sizes

lected had lesions only on the dorsal carapace) whereas male crabs showed relatively high occurrences of infection of their chelae and ventral surfaces as well as the dorsal carapace.

When the dorsal carapace was divided into 28 equal areas, a graded increase in infection towards the centre of the posterior margins was revealed (Fig. 6A) and the distribution between the right and left sides was symmetrical. The severity of infection ranged from 3.5 to 13.6 percentage cover of an area with a modal area

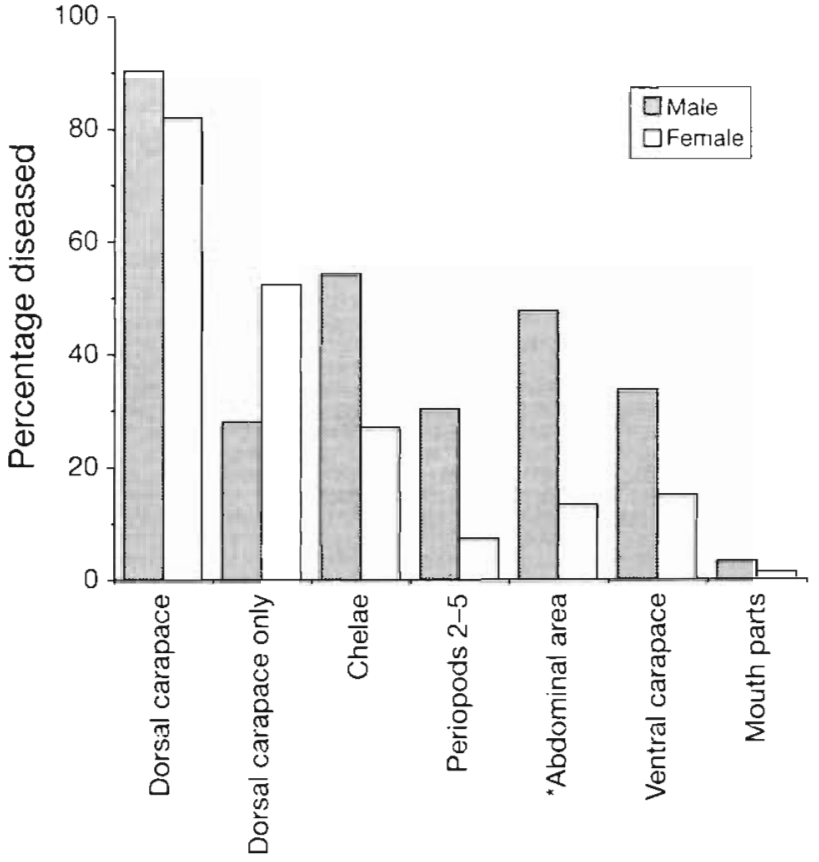

Fig. 5. Cancer pagurus. Prevalence of lesion occurrence on various anatomical regions of the exoskeleton in male and female crabs sampled between March (1997) and February (1998). Abdominal area is composed of the abdomen and thoracic sternum

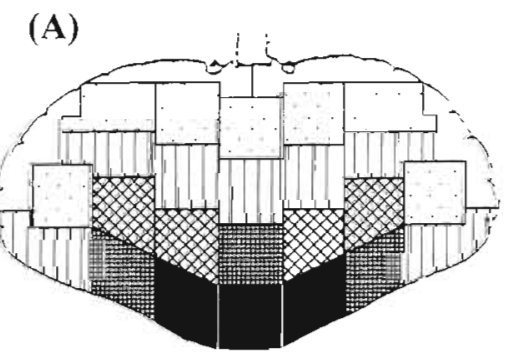

Percentage diseased

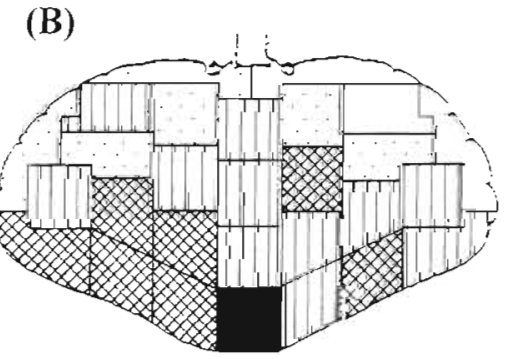

Percentage cover

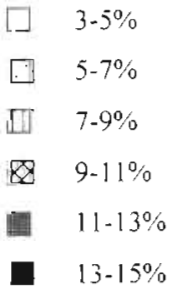

Fig. 6. Cancer pagurus. Prevalence severity of shell disease on the dorsal carapace of crabs. (A) Percentage of crabs with dorsal carapace infection that have regional infection $(\mathrm{n}=$ 245). (B) Percentage cover of the dorsal carapace regions with shell disease lesions. Regional values represent the mean percentage cover from only those crabs that display lesions in each respective area 


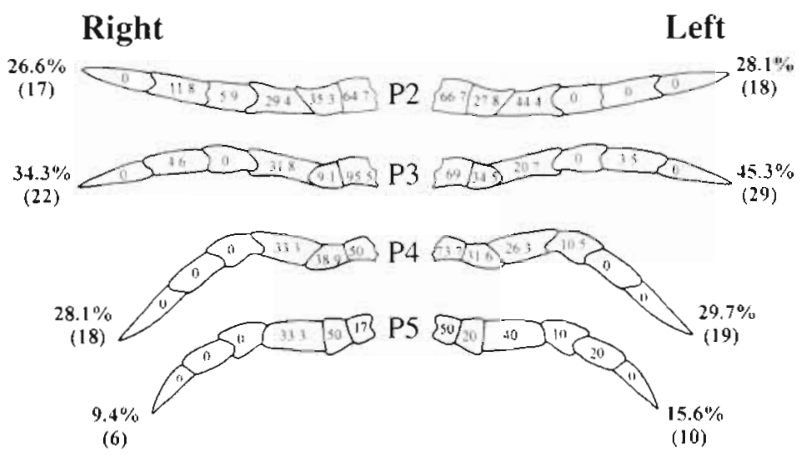

Fig. 7. Cancer pagurus. Diagrammatic representation of variation in prevalence and severity of shell disease on the ventral surfaces of the periopods (P) 2-5. Figures at limb tips: percentage of lesion occurrence on each of the 8 periopods in periopod-diseased animals $(n=64)$. Numbers in parentheses: actual numbers of crabs with 1 or more lesions on a particular limb. Numbers located within the limb segments: percentage of diseased individuals that have lesions occurring on each segment

value of 7 to $8 \%$ cover (Fig. 6B). The severity was also highest along the posterior margins, showing a maximum value in the central section along the posterior margin.

Amongst the crabs with lesions on the walking legs (periopods 2 to 5), the 3rd periopods (P3) were most frequently affected by disease lesions (Fig. 7). The 3 base segments of all walking legs showed the highest frequencies of lesion formation, with the coxa (the segment attached to the crab) the worst affected in all but 1 of the limbs. Periopod loss was significantly higher in males $(40.5 \%)$ than females $(26.4 \%)$ (Fisher's exact, $\mathrm{p}=0.0021$ ). Male crabs showed a significantly higher percentage of limb loss in diseased animals (49.5\%) compared to their disease-free counterparts (25.2\%) (Fisher's exact, $\mathrm{p}<0.0001$ ). No significant differences in limb loss were observed amongst the female diseased $(34.3 \%)$ and disease-free $(21.0 \%)$ groups (Fisher's exact, $\mathrm{p}=0.073$ ).

\section{DISCUSSION}

The prevalence of shell disease in the Cancer pagurus population onshore in Langland Bay between March 1997 and February 1998 was found to be $55.4 \%$. Lesions most commonly occurred on the dorsal carapace for both sexes. The predominance of lesions to the posterior of the carapace coupled with highest severity in this region suggests that abrasion of the epicuticle may occur as the crab burrows backwards into the sediment. This hypothesis is further supported by the majority of lesions on the walking legs occurring on the ventral surface of the coxa. The upper layers of sand sediment are known to support the highest number of chitinoclastic organisms (Hood \& Meyers 1973) and the chitin-rich material is rapidly colonised by microbes (Gooday 1990). Burial in the sediment not only abrades the epicuticle, but brings the exposed chitin into close contact with high numbers of microorganisms with the potential to degrade it. Hall et al. (1991, 1993) suggested that pit-digging in the edible $\mathrm{crab}$ in subtidal regions is a foraging activity. The onshore, intertidal burying behaviour observed in this study is more likely to offer protection from predators and protection from desiccation during low tide.

In agreement with Ayres \& Edwards (1982), it was found that shell disease in Cancer pagurus shows a higher prevalence and severity among larger individuals. An increase in levels of the disease with size has also been demonstrated for the brown shrimp Crangon crangon (Abbott 1977, Nottage 1982, Dyrynda 1998) and the American lobster Homarus americanus (Estrella 1990). C. pagurus, like many other crustaceans, shows a reduction in moult frequency with increase in carapace width (Edwards 1979). A longer intermoult period would give the chitinoclastic micro-organisms more time to colonise and degrade a larger proportion of the cuticle, thereby increasing the chances of penetration to the underlying epidermis, which may lead to the persistence of the infection through moult (Vervoort et al. 1980) or death during moult due to adhesion between old and new shells at the site of epidermal penetration (Fisher et al. 1978, Smolowitz et al. 1992). The observed drop in severity between the largest 2 size classes (Fig. 4B), may reflect mortality during the moult to reach the $\geq 140 \mathrm{~mm}$ size class, i.e. only those individuals that are less severely infected will survive the moult into the legal size class ( $\geq 140 \mathrm{~mm} \mathrm{CW}$ ).

As was found by Comely \& Ansell (1989), the current study shows that for Cancer pagurus the disease is more prevalent amongst males. Male $C$. pagurus from the English Channel moult more frequently than females; however, in the North Sea the opposite case applies (Bennett 1974). No information exists on the moult frequencies of males and females from the Bristol Channel (the current sample site). It is unlikely that a difference in moult frequency could account for the lesion location differences in males and females since both sexes display similar prevalences in dorsal carapace infection. The sexual differences lie in an increase in ventral surface and chela infection in males. Chela infections are probably the result of fighting injuries, which are likely to be more common in mature male (cock) crabs owing to their more aggressive nature (Warner 1977, Edwards 1979). The observed difference in ventral surface infection is more difficult to explain, but might result from behavioural and/or 
anatomical differences between the sexes of C. pagurus. Whilst onshore, male crabs were often observed on the backs of pre-moult females. This mounting behaviour could lead to ventral surface abrasions and eventually abdominal lesions. Ovigerous females are known to dig hollows in the sediment when spawning their eggs (Edwards 1979). The size and position of attachment of eggs to the abdomen make it impossible for ovigerous crabs to back-bury into the sediment in the same manner as that observed onshore. Since the egg-carrying lasts approximately 9 mo (Bennett 1995), it is possible that females do not encounter the same frequency of ventral surface abrasion as males. It may be argued that this area is more likely to encounter sediment abrasion injuries when berried; however, the gross anatomy of the female abdomen suggests it is more robust in comparison to the male (authors' pers. obs.). Clearly, there is a need for further structural analysis of male and female abdominal sections to authenticate this initial observation.

The inshore/offshore seasonal migration patterns for Cancer pagurus from Langland Bay are similar to those reported for populations around the British coastline (Pearson 1908, Edwards 1979). The inshore migration of crabs is thought to be temperature dependent, with the first crabs coming to shore when the surface water temperatures exceed $5^{\circ} \mathrm{C}$ (Karlsson \& Christiansen 1996). In Langland Bay, as water temperatures increase in spring, there appears to be an influx of smaller individuals $(<120 \mathrm{~mm} \mathrm{CW})$ for their first moult of the season (Fig. 2). Larger individuals (>120 mm $\mathrm{CW}$ ) that will moult once, or less than once, in a season (Hancock \& Edwards 1967) will probably not do so until the food availability has been sufficiently high to allow adequate feeding. Excluding immature (prepubescent) crabs, Edwards (1979), Brown \& Bennett (1980) and Karlsson \& Christiansen (1996) all report that the peak in the moulting period occurs earlier in females than males. Higher numbers of large males onshore throughout most of the moulting season may indicate male polygamy, as shown in laboratory studies by Edwards (1966), and a tendency for males to hold back their moult until most of the females have moved to offshore waters to find sediment suitable for the spawning of their eggs. The use of suture tagging would have been advantageous for tracking the migratory movements of crabs and particularly the mating habits of males. However, suture tags cannot be used in studies involving shell disease, since they penetrate and damage the exoskeleton, hence providing a potential anthropogenic focal point for invasion of micro-organisms.

Comely \& Ansell (1989) could find no seasonal variation in shell disease in the shore crab Carcinus maenas from Scottish waters. Our study shows that the sea- sonal patterns of shell disease are highly dependent on the sexual ratio and the proportion of size classes that make up the sample population. At Langland Bay, more males are present onshore at all times of the year; however, their relative proportion is seen to decrease in the summer when the larger reproductively active females arrive on shore to moult. Since males are shown to have higher levels of infection, one would predict the prevalence and severity of the disease to decline slightly over these months. This pattern may, however, be counteracted by a higher proportion of larger individuals present onshore over the summer months.

In conclusion, shell disease exists in $55 \%$ of the 500 Cancer pagurus sampled from the Langland Bay population. The study highlights worrying implications for commercial fishermen as a high proportion $(88 \%)$ of legal-sized crabs have advanced forms of the disease. This does not only affect the catch rejection figures, but may also lead to fewer reproductively active individuals surviving in the population.

Acknowledgements. We thank Wyn Morris for his expert knowledge of the shore and assistance with field collection and Dr S. J. Wainwright for advice on statistical analysis. C.L.V. was supported by a University of Wales studentship.

\section{LITERATURE CITED}

Abbott OJ (1977) Black necrosis in the brown shrimp, Crangon crangon. In: Nelson-Smith A, Bridges EM (eds) Problems of a small estuary. Quadrat Press Ltd, Swansea, p 3: $2 / 1-3: 2 / 10$

Anderson JTW, Conroy DA (1968) The significance of disease in preliminary attempts to raise Crustacea in sea water. Bull Off Int Épizoot 69:1239-1247

Ayres PA, Edwards E (1982) Notes on the distribution of 'black spot' shell disease in crustacean fisheries. Chem Ecol 1:125-130

Baross JA, Tester PA, Morita RY (1978) Incidence, microscopy, and etiology of exoskeletal lesions in the tanner crab, Chionoecetes tanneri. J Fish Res Board Can 35 : $1141-1149$

Bennett DB (1974) Growth of the edible crab (Cancer pagurus) off south-west England. J Mar Biol Assoc UK 54: $803-823$

Bennett DB (1995) Factors in the life history of the edible crab (Cancer pagurus L.) that influence modelling and management. ICES Mar Sci Symp 199:89-98

Brown CG, Bennett DB (1980) Population and catch structure of the edible crab (Cancer pagurus) in the English Channel. J Cons Int Explor Mer 39:88-100

Chan S, Rankin SM, Keeley LL (1988) Characterisation of the molt stages in Penaeus vannamei: setogenesis and hemolymph levels of total protein, ecdysteroids and glucose. Biol Bull 175:185-192

Cipriani GR, Wheeler RS, Sizemore RK (1980) Characterization of brown spot disease of gulf coast shrimp. J Invertebr Pathol 36:255-263

Comely CA, Ansell AD (1989) The occurrence of black 
necrotic disease in crab species from the west of Scotland. Ophelia 30:95-112

Cook DW, Lofton SR (1973) Chitinoclastic bacteria associated with shell disease in Penaeus shrimp and the blue crab (Callinectes sapidus). J Wild Dis 9:154-159

Doughtie DG, Rao KR (1981) The synctial nature and phagocytic activity of the branchial podocytes in the grass shrimp, Palaemonetes pugio. Tissue Cell 13:93-104

Drach P (1939) Mue et cycle d'intermue chez les Crustacés décapodes. Ann Inst Océanogr Monaco 19:103-391

Dyrynda EA (1998) Shell disease in the common shrimp Crangon crangon (L.): variations and possible causes within an enclosed estuarine system. Mar Biol 132:445-452

Edwards E (1966) Mating behaviour in the European edible crab (Cancer pagurus L.). Crustaceana 10:23-30

Edwards E (1979) The edible crab and its fishery in British waters. Fishing New Books Ltd., Farnham, Surrey

Estrella BT (1990) Shell disease in the American lobster off the Massachusetts coast. J Shellfish Res 8:461

Fisher WS, Nilson EH, Steenbergen JF, Lightner DV (1978) Microbial diseases of cultured lobsters: a review. Aquaculture 14:115-140

Getchell RG (1989) Bacterial shell disease in crustaceans: a review. J Shellfish Res 8:1-6

Gooday GW (1990) The ecology of chitin degradation. Adv Microb Ecol 11:387-430

Gopalan UK, Young JS (1975) Incidence of shell disease in shrimp in the New York Blight. Mar Pollut Bull 6:149-153

Hall SJ, Basford DJ, Robertson MR, Raffaelli DG, Tuck I (1991) Patterns of recolonisation and the importance of pit-digging by the crab Cancer pagurus in the subtidal sand habitat. Mar Ecol Prog Ser 72:93-102

Hall SJ, Robertson MR, Basford DJ, Fryer R (1993) Pit-digging by the crab Cancer pagurus: a test for long-term, large scale effects on infaunal community structure. J Anim Ecol 62:59-66

Hancock DA, Edwards E (1967) Estimation of annual growth

Editorial responsibility: Timothy Flegel,

Bangkok, Thailand in the edible crab (Cancer pagurus L.). J Cons Int Explor Mer 31:246-264

Hood MA, Meyers SP (1973) The biology of aquatic chitinoclastic bacteria and their chitinoclastic activities. La Mer 11:213-229

Karlsson K, Christiansen ME (1996) Occurrence and population composition of the edible crab (Cancer pagurus) on rocky shores of an islet on the south coast of Norway. Sarsia 81:307-314

Nottage AS (1982) Shell disease of the brown shrimp. Crangon crangon (L.), and other marine Crustacea from The Solway Firth. Chem Ecol 1:107-123

Pearson J (1908) Cancer. Liverpool Marine Biology Committee Memoirs, Vol 16. Williams \& Norgate, London

Rosen B (1970) Shell diseases of aquatic crustaceans. In: SF Snieszko (ed) A symposium on diseases of fishes and shellfishes. Spec. publ. no. 5. American Fisheries Society, Washington, DC, p 409-415

Sindermann CJ (1984) Disease in marine aquaculture. Helgol Wiss Meeresunters 37:505-532

Sindermann CJ, Rosenfield A (1967) Principal diseases of commercially important bivalve Mollusca and marine Crustacea. Fish Bull 66:335-385

Smolowitz RM, Bullis RA, Abt DA (1992) Pathologic cuticular changes of winter impoundment shell disease preceding and during intermolt in the American Lobster, Homarus americanus. Biol Bull 183:99-112

Vervoort D, Redant F, Declerck D (1980) Causes and incidence of 'black spot disease' on brown shrimp (Crangon crangon). ICES (Comm Meet Pap Rep) K: 34:1-14

Warner GF (1977) The biology of crabs. Elek Science, London

Weinstein JE, West TL, Bray JT (1992) Shell disease and metal content of blue crabs, Callinectes sapidus, from the Albemarle-Palmlico Estuarine System, North Carolina. Arch Environ Contam Toxicol 23:355-362

Young JS, Pearce JB (1975) Shell disease from crabs and lobsters from New York Bight. Mar Pollut Bull 6:101-105

Submitted: July 29, 1998; Accepted: October 12, 1998

Proofs received from author(s): January 14, 1999 